\title{
ORGANIC CARBON CONTENT AND FE-ORGANO ASSOCIATION IN SOILS UNDER RICE DOMINANT CROPPING SYSTEM IN BANGLADESH
}

\author{
Puja Biswas, Md Sanaul Islam, Abu Bakor Siddique ${ }^{1}$ and Milton Halder*
}

Soil, Water and Environment Discipline, Khulna University, Khulna-9208, Bangladesh

Keywords: Soil organic carbon, Cropping system, Organically complexed Fe oxides, Fe-organo association

\begin{abstract}
Soil organic carbon (SOC) storage is significant for nutrient recycling and mitigation of greenhouse gasse-emission from soil environment. It is investigated as to how SOC is varied and stored at iron (Fe) interface under different cropping systems. Thus, the experiment was conducted at three cropping systems consisted as Fallow-Fallow-Fallow (FL), Fallow - Fallow - Rice (OC), Fallow- Rice - Rice (TC). Soil samples were collected from the indicated cropping systems and three parameters were assessed: SOC, amorphous $\mathrm{Fe}$ oxides $\left(\mathrm{Fe}_{\mathrm{o}}\right)$ and organically complex $\mathrm{Fe}\left(\mathrm{Fe}_{\mathrm{p}}\right)$ oxides. The results revealed that SOC content reduced significantly $(\mathrm{p}<0.05)$ in the order of $\mathrm{FL}<\mathrm{OC}<\mathrm{TC}$. $\mathrm{Fe}_{\mathrm{o}}$ and $\mathrm{Fe}_{\mathrm{p}}$ oxides also reduced significantly under OC and TC cropping systems compared to FL. A significant $(\mathrm{p}<0.01)$ positive correlation between $\mathrm{Fe}_{\mathrm{o}}$ and $\mathrm{Fe}_{\mathrm{p}}$ oxides with SOC ( $\mathrm{r}=0.93, \mathrm{r}=0.86$, respectively) was observed. The results suggest that $\mathrm{Fe}_{\mathrm{o}}$ and $\mathrm{Fe}_{\mathrm{p}}$ play a significant role to improve SOC storage through complex formation in soils of rice dominant cropping system.
\end{abstract}

Soil organic carbon (SOC) storage is a promising measure to mitigate climate changes through C sequestration (Lal 2004). SOC plays an important role and act as a pool of terrestrial Cin ecosystem productivity, the functioning of agroecosystems and cropland fertility. Alteration of nutrients fluxes in soil and terrestrial ecosystems causes through global land use changes such as deforestation, cultivation, erosion and reforestation (Fraterrigo et al. 2005). Soil manipulation by tillage and change of land use pattern affect SOC accumulation in cropland. It has been found that short-term $\mathrm{CO}_{2}$ evolution and microbial biomass turnover enhanced through tillage and oxidation to $\mathrm{CO}_{2}$ accelerated by improving soil aeration as well as by increasing contact between soil and crop residues, and by exposing aggregate-protected organic matter to microbial attack (Beare $e t$ al. 1994). Due to intensive cultivation, SOC content is reduced and oxidation of SOC accelerates (Abera and Belachew 2011). Eusterhues et al. (2005) indicated that structural organization of organic matter $(\mathrm{OM})$ and mineral constitutions in organo-mineral associations are the major mechanism of soil organic matter (SOM) stabilization. In this connection 3 major factors have been proposed to SOC stabilization against decomposition and they are: (i) chemical recalcitrance, (ii) spatial inaccessibility and (iii) interaction with mineral surfaces (phyllosilicates, oxides of Fe and Al) (Lutzow et al. 2006). From the literature of Dümig et al. (2012) and Kiem and KögelKnabner (2002) it is known that there is a positive correlation between SOM content and mineral constitutions as there is a possibility of adsorption of SOM on large surface area of soil minerals (Wagai and Mayer 2007) or they have the ability to interconnect particles to aggregates (Eusterhues et al. 2005). Wiseman and Puttmann (2006) concluded that oxides, particularly amorphous or non-crystalline forms, appear to be strongly associated with SOC. It has been found that $\mathrm{OM}$ in acid soils which interacts with poorly crystalline minerals represented by oxalatesoluble iron $(\mathrm{Fe})$ and aluminium ( $\mathrm{Al})$ fractions is preferentially protected (Kleber et al. 2005). *Author for correspondence: soilmilton06@gmail.com. ${ }^{1}$ Bangladesh Council of Scientific and Industrial
Research (BCSIR), Dhaka-1205, Bangladesh. 
Despite the presence of smaller concentrations of poorly crystalline iron Duiker et al. (2003) have found that crystalline $\mathrm{Fe}$ is less effective than poorly crystalline $\mathrm{Fe}$ in stabilizing soil aggregates. Many studies have shown that long-term application of organic fertilizer could increase SOC content significantly (Sommerfeldt et al. 1988, Edmeades 2003) but the effects of different cropping systems under rice dominant paddy field on SOC storage, Fe amorphous and organically complexed form and the relationship between SOC and Fe oxides were not examined thoroughly. However, the understanding of the degree and mechanisms of organic coverage on $\mathrm{Fe}$ surfaces is still incomplete (Lützow et al. 2006). It may be hypothesized at different cropping systems influence SOC storage and Fe oxides (especially amorphous and organically bound $\mathrm{Fe}$ ) and relationship between them.

Soil samples were collected from rice dominant cropping systems inside of Khulna University area of Bangladesh. Samples were collected from three cultivated fields as fallow land (FL), one season (OC) and two season rice (TC) cultivating land at three depths $(0-15,15-30,30-45 \mathrm{~cm})$ with each of three replications. The three vertical soil depth were selected to evaluate the impact of tillage on soil organic carbon distribution. Fallow land was kept fallow throughout the year. Grasses and weeds were grown around the year. All the plants in fallow land were cut and kept on the field in each year. Then, in OC cropping system rice was cultivated for one season throughout the year. Conventional tillage practice was used for both (OC and TC) cropping system. Straw was not handled carefully for conservation tillage. Before rice cultivation and after harvesting the lands were kept fallow and straw was collected from field for domestic use. Rice seedlings are grown in seedbed then transplanted to main field. Flooding types of irrigation was practiced and only recommended inorganic fertilizer was applied. Lastly for TC cropping system, rice was grown two seasons every year. In the first one rice seeds were broadcasted (December/January) evenly over the cultivated land. Flooding types of irrigation and recommended dose of inorganic fertilizers were applied. After harvesting, all the rice plants were carried from the cropland. In the second one all the practices were same to first one but except for seeds broadcasting. Here, rice seeds were sown in separate seedbed then transplanted in main field. All the sampling sites belong to the physiography of Ganges tidal flood plain and under low land type area. Additional information regarding to sampling sites are summarized in Table 1.

Table 1. Basic information about sampling sites.

\begin{tabular}{llll}
\hline Sampling field name & Soil series & GPS location & Cropping systems \\
\hline FL (Fallow land) & Dumuria & $22^{\circ} 48.312^{\prime} \mathrm{N}$ & Fallow - Fallow - Fallow \\
& & $89^{\circ} 31.794^{\prime} \mathrm{E}$ & \\
OC (One season rice cultivation) & Dumuria & $22^{\circ} 48.230^{\prime} \mathrm{N}$ & Fallow - Fallow - Rice \\
& & $89^{\circ} 31.878^{\prime} \mathrm{E}$ & \\
TC (Two season rice cultivation) & Dumuria & $22^{\circ} 48.247^{\prime} \mathrm{N}$ & Fallow - Rice - Rice \\
& & $89^{\circ} 31.870^{\prime} \mathrm{E}$ & \\
\hline
\end{tabular}

Soil organic $\mathrm{C}$ was determined by oxidation of organic carbon with potassium dichromate and sulfuric acid as described in Walkley and Black's wet oxidation method (Jackson 1962).

Amorphous or poorly crystalline $\mathrm{Fe}\left(\mathrm{Fe}_{\mathrm{o}}\right)$ oxides were measured by extraction with acid ammonium oxalate $(0.2 \mathrm{M})$ at $\mathrm{pH} 3.0$ under dark conditions and 4 hrs shaking in reciprocating shaker. The organically complexed $\mathrm{Fe}\left(\mathrm{Fe}_{\mathrm{p}}\right)$ oxides were extracted by sodium-pyrophosphate $(0.1 \mathrm{M})$ at $\mathrm{pH} 10$ with $16 \mathrm{hrs}$ shaking (Ross and Wang 1993). Fe concentration in the solution after extraction was analyzed by Atomic Absorption Spectrophotometer (AAS). 
Statistical analyses were conducted by using SPSS 13.0. Analysis of variance (ANOVA) was used to explore the effects of cropping systems on SOC storage and $\mathrm{Fe}$ oxides $\left(\mathrm{Fe}_{\mathrm{o}}, \mathrm{Fe}_{\mathrm{p}}\right)$ (SPSS 2004). The relationship between $\mathrm{SOC}$ and $\mathrm{Fe}_{\mathrm{o}}, \mathrm{Fe}_{\mathrm{p}}$ oxides were examined by calculating the Pearson's correlation coefficient (r) with the SPSS 13.0 program.

Soil organic carbon was declined significantly $(\mathrm{p}<0.05)$ under TC and OC cropping systems compared to FL in both soil depth (0 - 15 and $15-30 \mathrm{~cm}$ depth) but SOC in $30-45 \mathrm{~cm}$ depth also decreased in OC and TC system compared to FL but not significant (Fig. 1). SOC also significantly $(\mathrm{p}<0.05)$ reduced in the vertical soil depth in each cropping systems separately.

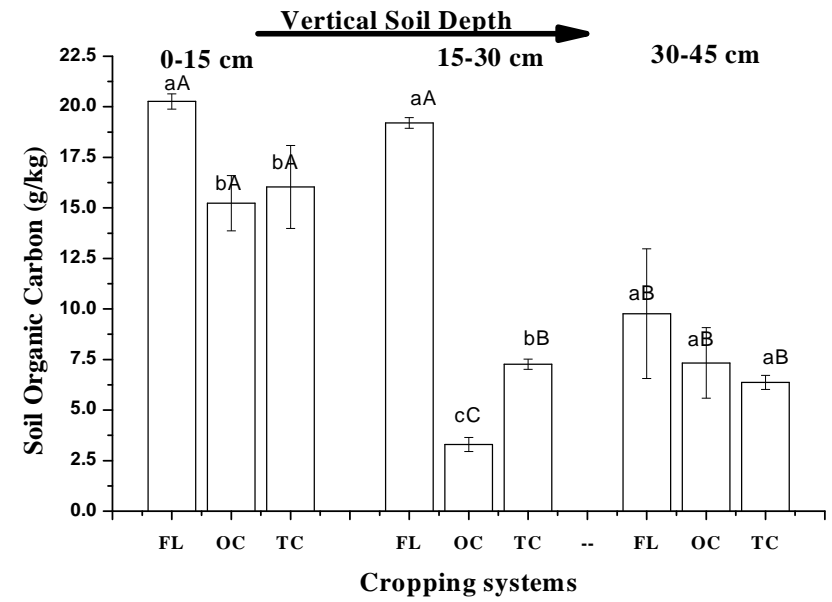

Fig. 1. Effects of cropping systems and vertical soil depth on soil organic C storage. (Small letters indicate the comparison among the cropping systems and capital letters indicate comparison among the vertical soil depth in each cropping system at 0.05 levels. Error bars represent standard deviation of means, $n=3$ ).

In this study SOC content varied with cropping systems which corroborates with Celik (2005) and Riezebos and Loerts (1998). Cultivated land captured lowest amount of soil organic C than fallow land. Celik (2005) reported that undisturbed land promotes more soil organic C storage than land disturbed by tillage intensity. In this study, SOC content was found to reduce with increasing intensity of cultivation (FL > OC > TC). The lowest soil organic matter content in more cultivated fields could be due to reduced inputs of $\mathrm{C}$ as well as frequent soil manipulation by tillage which promote oxidation of SOC (Abera and Belachew 2011). Riezebos and Loerts (1998) reported that fallow lands accumulate less organic carbon than cultivated land where conservation tillage is practiced. But in the present research fields no conservation tillage was practiced. The results obtained in this study indicate that SOC concentration reduced significantly with increasing vertical soil depth for different cropping systems and the highest $\mathrm{C}$ content was recorded in surface soil layer. Cropping systems influenced SOC storage up to $30 \mathrm{~cm}$ depth but below $30 \mathrm{~cm}$ depth no influence was observed. Most interesting result was that with FL cropping systems SOC storage declined below $30 \mathrm{~cm}$ while with intensive cropping (OC and TC) systems SOC declined only below $15 \mathrm{~cm}$ from surface. This might be due to intensive cultivation helps more soil aeration which promotes organic matter oxidation.

Amorphous iron $\left(\mathrm{Fe}_{\mathrm{o}}\right)$ oxides content was influenced significantly $(\mathrm{p}<0.05)$ with increasing intensity of rice cultivation. $\mathrm{Fe}_{\mathrm{o}}$ oxides content declined under $\mathrm{OC}$ and $\mathrm{TC}$ cropping systems in compare to FL. In vertical soil depth, Fe content particularly amorphous form was found to 
decrease statistically $(\mathrm{p}<0.05)$ in sub soil $(30-45 \mathrm{~cm})$ compared to topsoil $(0-15 \mathrm{~cm})$ under all cropping system (Fig. 2A). A significant positive correlation $(r=0.93, p<0.01)$ between the amorphous iron oxides $\left(\mathrm{Fe}_{\mathrm{o}}\right)$ and soil organic $\mathrm{C}$ was observed (Fig. $\left.2 \mathrm{~B}\right)$.

A

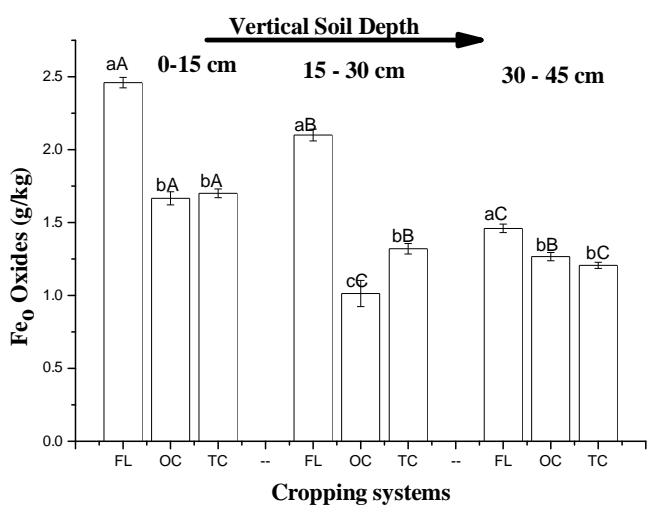

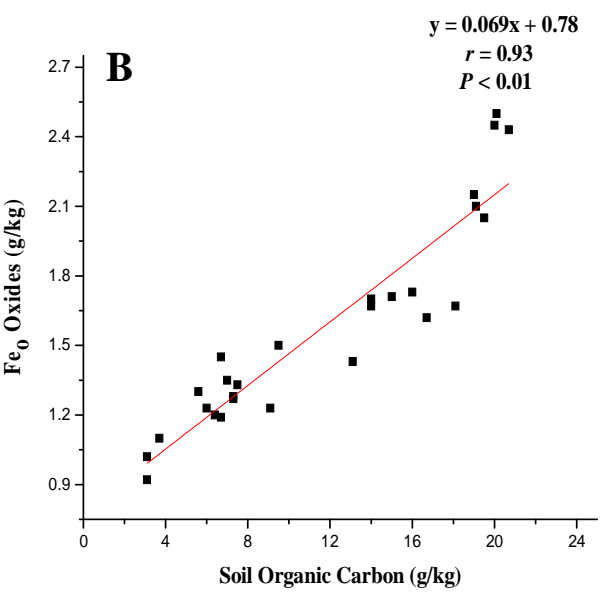

Fig. 2. Effects of cropping systems and vertical soil depth on amorphous iron $\left(\mathrm{Fe}_{\mathrm{p}}\right)$ oxides $(\mathrm{A})$ and correlation between organic carbon (SOC) and amorphous iron oxides $\left(\mathrm{Fe}_{\mathrm{o}}\right)(\mathrm{B})$. Small letters indicate the comparison among the cropping systems and capital letters indicate comparison among the vertical soil depth in each cropping systems at 0.05 levels. Error bars represent standard deviation of means, $\mathrm{n}=3$.

Stabilization of soil organic $\mathrm{C}$ is greatly influenced by soil minerals and soil aggregation (Lutzow et al. 2006). Paul et al. (2008) found that organo-mineral complex formation for soil aggregation is more important for soils which retain more $\mathrm{Fe}$ and $\mathrm{Al}$ oxides. Torn et al. (1997) reported that soil organic $\mathrm{C}$ storage and turnover are controlled by oxides of iron. Soil organic $\mathrm{C}$ mineralization process is also mediated greatly by iron oxides and hydroxides (Rasmussen $e$ al . 2006). Wiseman and Puttmann (2006) found soil organic C to be strongly associated with amorphous or noncrystalline Fe oxides concentration. The reason of this outcome can be explained by the findings of Eusterhues et al. (2005) and Torn et al. (1997). They found that amorphous or noncrystalline Fe oxides has greater specific surface area to stabilize soil organic C. Berhe et al. (2012) reported that soil organic $\mathrm{C}$ is stored with amorphous or noncrystalline iron oxides proportionally, form metastable with Fe and complex with soil minerals.

Organically complex $\mathrm{Fe}$ oxides $\left(\mathrm{Fe}_{\mathrm{p}}\right)$ content in $\mathrm{OC}$ and $\mathrm{TC}$ cropping systems reduced significantly ( $\mathrm{p}<0.05$ ) compared to FL (Fig. 3). But in fallow land (FL) $\mathrm{Fe}_{\mathrm{p}}$ content was found decrease gradually and significantly $(\mathrm{p}<0.05)$ throughout the vertical depth. Otherwise, there was no statistical significant difference of $\mathrm{Fe}_{\mathrm{p}}$ oxides under $\mathrm{TC}$ field along the vertical soil layer but $\mathrm{Fe}_{\mathrm{p}}$ oxides under $\mathrm{OC}$ cropping system varied abruptly with increasing soil depth (Fig. 4). A significant $(\mathrm{r}=0.86, \mathrm{p}<0.01)$ positive correlation between soil organic $\mathrm{C}$ and organically complexed iron $\left(\mathrm{Fe}_{\mathrm{p}}\right)$ oxides was obtained (Fig. 3). The combined effect of cropping systems and vertical soil depth on soil organic $\mathrm{C}$, amorphous and organically complexed $\mathrm{Fe}$ oxides was also significant $(\mathrm{p}<0.001)$ and illustrated in Table 2. 

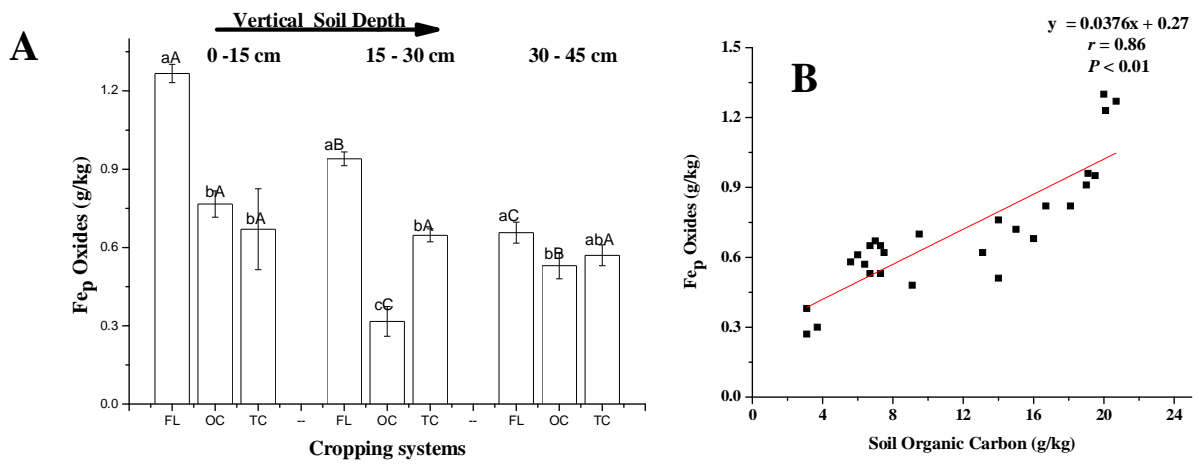

Fig. 3. Effect of cropping systems and vertical soil depths on organically bound iron ( $\mathrm{Fe}_{\mathrm{p}}$ ) oxides (A) and relationship between $\mathrm{Fe}_{\mathrm{p}}$ and $\mathrm{SOC}(\mathrm{B})$. (Small letters indicate the comparison among the cropping systems and capital letters indicate comparison among the vertical soil depth in each cropping systems at 0.05 levels. Error bars represent standard deviation of means, $n=3$ ).

Table 2. Combined effects of cropping systems and soil depth on $\mathrm{SOC}, \mathrm{Fe}_{\mathrm{o}}$ and $\mathrm{Fe}_{\mathrm{p}}$.

\begin{tabular}{llll}
\hline Analysis of variance & $\mathrm{SOC}$ & $\mathrm{Fe}_{\mathrm{o}}$ & $\mathrm{Fe}_{\mathrm{p}}$ \\
\hline Depth & $* * *$ & $* * *$ & $* * *$ \\
Cropping practices & $* * *$ & $* * *$ & $* * *$ \\
Depth* cropping practices & $* * *$ & $* * *$ & $* * *$ \\
\hline
\end{tabular}

Results revealed that amorphous and organically complexed Fe oxides increased significantly with soil organic $\mathrm{C}$ content among the cropping systems and reduced significantly with vertical soil depth. A positive correlation was also found between $\mathrm{Fe}_{\mathrm{p}}$ and $\mathrm{Fe}_{\mathrm{p}}$ oxides with soil SOC. The result was similar to that of several reports (Wiseman and Puttmann 2006, Paul et al. 2008, Rachel et al. 2017). This suggests that SOC input improves amorphous form of Fe oxides which promotes capture and storage of SOC in cultivated soils.

SOC content reduced significantly $(\mathrm{p}<0.05)$ with increasing rice cultivation intensity. Fe oxides, particularly amorphous and organically complexed form declined in OC and TC cropping systems compared to fallow land (FL). A significant $(\mathrm{p}<0.01)$ positive correlation was also found between $\mathrm{Fe}_{\mathrm{p}}$ and $\mathrm{Fe}_{\mathrm{p}}$ oxides with soil organic $\mathrm{C}$ which indicated that amorphous $\mathrm{Fe}$ contributes to storage SOC due to more reactive surface area for complex formation.

\section{References}

Abera TY and Belachew T 2011. Effects of land use on soil organic carbon and nitrogen in soils of bale, southeastern Ethiopia [Efecto del uso del suleosobre el contendio de carbonoorganico y nitrogeno del suelo en bale, etiopia]. Tropical Subtropical Agroecosystem 14(1): 229-235.

Beare MH, Cabrera ML, Hendrix PF and Coleman DC 1994. Aggregate-protected and unprotected organic matter pools in conventional-and no-tillage soils. Soil Science Society of America Journal 58: 787-795.

Berhe AA, Suttle KB, Burton SD and Banfield JF 2012. Contingency in the direction and mechanics of soil organic matter responses to increased rainfall. Plant and Soil 358(1-2): 371-383.

Celik I 2005. Land-use effects on organic matter and physical properties of soil in a southern Mediterranean highland of Turkey. Soil Tillage Research 83(2): 270-277.

Dümig A, Häusler W, Steffens M and Kögel-Knabner I 2012. Clay fractions from a soil chronosequence after glacier retreat reveal the initial evolution of organo-mineral associations. Geochimica et Cosmochimica Acta 85: 1-18 
Duiker SW, Rhoton FE, Torrent J, Smeck NE and Lal R 2003. Iron (hydr) oxidecrystallinity effects on soil aggregation. Soil Science Society of American Journal 67(2): 606-611.

Edmeades DC 2003. The long-term effects of manures and fertilizers on soil productivity and quality: A review. Nutrient Cycle in Agroecosystem 66(2): 165-180.

Eusterhues K, Rumpel C and Kogel-Knabner I 2005. Organo-mineral associations in sandy acid forest soils: importance of specific surface area, iron oxides and micropores. European Journal of Soil Science 56(6): 753-763.

Fey MN and LeRoux J 1977. Properties and quantitative estimation of poorly crystalline components in sesquioxides soil clays. Clays Clay Mineral 25: 285-294

Fraterrigo JM, Turner MG, Pearson SM and Dixon P 2005. Effects of past land use on spatial heterogeneity of soil nutrients in southern Appalachian forests. Ecological Monograph 75(2): 215-230.

Jackson ML 1962. Soil Chemical Analysis. Prentice-Hall of Englewood cliffs, USA.

Kiem R and Kögel-Knabner I 2002. Refractory organic carbon in particle-size fractions of arable soils II: organic carbon in relation to mineral surface area and iron oxides in fractions $<6 \mu \mathrm{m}$. Organic Geochemistry 33(12): 1699-1713.

Kleber M, Mikutta R, Torn MS and Jahn R 2005. Poorly crystalline mineral phases protect organic matter in acid subsoil horizons. European Journal of Soil Science 56(6): 717-725.

Lal R 2004. Soil carbon sequestration impacts on global climate change and food security. Science 304(5677): 1623-1627.

Lutzow MV, Kogel-Knabner I, Ekschmitt K, Matzner E, Guggenberger G, Marschner B and Flessa H 2006. Stabilization of organic matter in temperate soils: mechanisms and their relevance under different soil conditions-a review. European Journal of Soil Science 57(4): 426-445.

Paul S, Flessa H, Veldkamp E and L'opez-Ulloa M 2008. Stabilization of recent soil carbon in the humid tropics following land use changes: Evidence from aggregate fractionation and stable isotope analyses. Biogeochemistry 87(3): 247-263.

Rasmussen C, Southard RJ and Horwath WR 2006. Mineral control of organic carbon mineralization in a range of temperate conifer forest soils. Global Change Biology 12(5): 834-847.

Rachel C. Porras, Caitlin E. Hicks Pries, Karis J. McFarlane, Paul J. Hanson and Margaret S. Torn 2017. Association with pedogenic iron and aluminum: Effects on soil organic carbon storage and stability in four temperate forest soils. Biogeochemistry 133: 333-345.

Riezebos HT and Loerts AC 1998. Influence of land use change and tillage practices on soil organic matter in southern Brazil and Eastern Paraguay. Soil and Tillage Research 49(3): 271-275.

Roose E and Barthès B 2001. Organic matter management for soil conservation and productivity restoration in Africa: a contribution from Francophone research. Nutrient Cycling in Agroecosystem 61: 159-170.

Ross GJ and Wang C 1993. Extractable Al, Fe, Mn, and Si. In: Carter MR (ed) Amnual on soil sampling and methods of analysis. Canadian Society of Soil Science, pp. 239-246.

Sommerfeldt T, Chang C and Entz T 1988. Long-term annual manure applications increase soil organic matter and nitrogen and decrease carbon to nitrogen ratio. Soil Science Society of American Journal 52(6): 1668-1672.

SPSS 2004. SPSS 13.0 for window. SPSS Inc., Chicago.

Torn MS, Trumbore SE, Chadwick OA, Vitousek PM and Hendricks DM 1997. Mineral control of soil organic carbon storage and turnover. Nature 389(6647): 170-173.

Wagai R and Mayer LM 2007. Sorptive stabilization of organic matter in soils by hydrous iron oxides. Geochimica et Cosmochimica Acta 71: 25-35.

Wiseman CLS and Puttmann W 2006. Interactions between mineral phases in the preservation of soil organic matter. Geoderma 134(1-2): 109-118. 